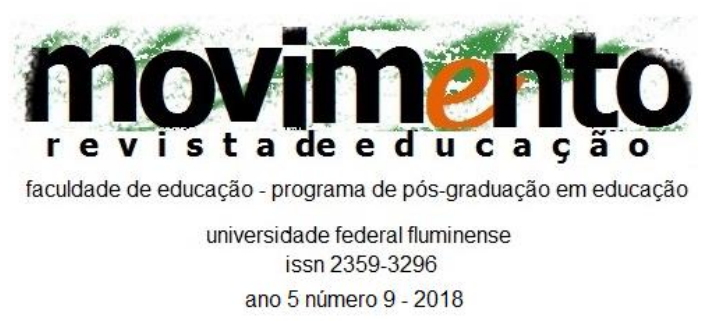

\title{
ACESSO E PERMANÊNCIA DOS ALUNOS POBRES NOS CURSOS MAIS SELETIVOS DA UNIVERSIDADE FEDERAL DO ACRE-UFAC, CAMPUS FLORESTA
}

\author{
Adriana Martins de Oliveira \\ Universidade Federal do Acre, \\ Cruzeiro do Sul, AC, Brasil \\ Ednaceli Abreu Damasceno \\ Universidade Federal do Acre, \\ Rio Branco, AC, Brasil
}

\begin{abstract}
Resumo
Esse artigo tem como objetivo analisar o acesso e a permanência de estudantes pobres nos cursos mais seletivos da Universidade Federal do Acre, Campus Floresta, bem como as estratégias adotadas por eles e pelos seus familiares. Para a realização deste estudo, foram adotados procedimentos quantitativos e qualitativos, com uso de questionário e entrevista semiestruturada. Dessa maneira, constatou-se que o acesso e a permanência dos estudantes pobres no ensino superior deve-se a força do atributo familiar, bem como do ambiente doméstico educógeno, que estimula a escolaridade dos filhos na universidade pública.

Palavras-chave: Acesso e permanência; Ensino Superior; alunos pobres.
\end{abstract}

\section{ACCESS AND PERMANENCE OF POOR STUDENTS IN THE MOST SELECTIVE COURSES OF THE FEDERAL UNIVERSITY}

\begin{abstract}
This article aims to analyze the access and permanence of poor students in the most selective courses of the Federal University of Acre, Campus Floresta, as well as the strategies adopted by them and their families to access and remain in the institution. Quantitative and qualitative procedures were adopted, using questionnaire and semistructured interview. It was verified that the access and the permanence of the poor students in the higher education is due to the strength of the family attribute, of the educogen domestic environment, that stimulates the schooling of the children in the public university.

Keywords: Access and permanence; Highereducation; Poorstudents.
\end{abstract}




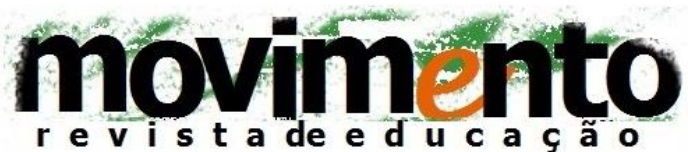 \\ faculdade de educação - programa de pós-graduação em educação \\ universidade federal fluminense \\ issn 2359-3296 \\ ano 5 número 9 - 2018}

\section{ACCESO Y PERMANENCIA DE LOS ALUMNOS POBRES EN LOS CURSOS MÁS SELECTIVOS DE LA UNIVERSIDAD FEDERAL}

\section{Resumen}

Este artículo tiene como objetivo analizarelacceso y lapermanencia de estudiantes pobres enlos cursos más selectivos de laUniversidad Federal de Acre, Campus Bosque, así como lasestrategias adoptadas por ellos y sus familiares para teneracceso y permanecer enlainstitución. Se adoptaronprocedimientoscuantitativos y cualitativos, con uso de cuestionario y entrevista semiestructurada. Se constató que elacceso y lapermanencia de losestudiantes pobres enlaenseñanza superior se debe a lafuerzadel atributo familiar, del ambiente doméstico educativo, que estimula laescolaridad de loshijosenlauniversidad pública.

Palabras claves: Acceso y permanência; Enseñanza superior; AlumnosPobres.

\section{Introdução}

O acesso e a permanência no ensino superior do Brasil tem como característica peculiar a seletividade e a desigualdade, constituindo-se em formas de exclusão e de grande desafio para o processo de democratização da universidade.

Algumas dessas formas de exclusão são bastante evidentes e quantificáveis, se considerarmos que apenas $14,6 \%$ dos jovens com idade entre 18 e 24 anos estavam matriculados na educação superior em 2015 (BRASIL, MEC, INDICADORES, 2015). Quando comparamos a situação brasileira com a de países vizinhos na mesma época, o Brasil não está bem colocado, uma vez que, na Argentina, $40 \%$ da população nessa faixa etária já frequentava 0 ensino superior, no Chile, 20,6\%, na Venezuela, 26\% e, na Bolívia, 20,6\% (SOUZA, 2013).

Esse panorama de desigualdades vem se perpetuando e apresenta uma nítida relação entre renda familiar e possibilidades de acesso ao ensino superior. Assim, o sistema educacional brasileiro apresenta-se excludente desde os 


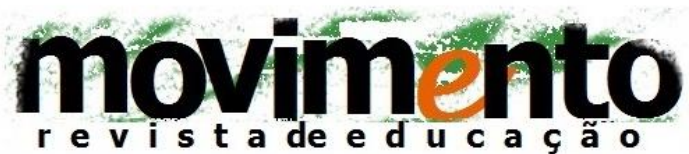 \\ faculdade de educação - programa de pós-graduação em educação \\ universidade federal fluminense \\ issn 2359-3296 \\ ano 5 número 9 - 2018}

níveis anteriores ao universitário, afina, cerca de $16 \%$ dos adolescentes brasileiros, entre 15 e 17 anos, encontram-se fora das salas de aula e apenas $32 \%$ dos brasileiros têm ensino médio completo. Esses dados mostram-nos a gravidade do quadro educacional brasileiro e a complexidade das desigualdades sociais relacionadas a ele (PAULA, 2011).

Vale salientar como causas da exclusão e da desigualdade no acesso ao ensino superior a escassez orçamentária destinada à educação superior pública, a qualidade deficiente na educação básica pública (também associada ao financiamento público), a privatização e a mercantilização da educação superior e a incapacidade de vastos setores sociais de pagar pelas matrículas.

Há ainda os fatores internos às instituições de ensino superior que também influenciam fortemente na reprodução das desigualdades educacionais e sociais, dificultando o acesso e a permanência dos estudantes. Dentre esses, é pertinente ressaltar os sistemas de ingresso muito seletivos, currículos pouco flexíveis e afastados da realidade dos alunos e a escassez de políticas de assistência e afirmativas e compensatórias ${ }^{1}$ que realmente contribuam não apenas para a inserção, mas também para a permanência dos alunos pobres ${ }^{2}$.

\footnotetext{
${ }^{1}$ Teoria Compensatória lastreia-se na retificação de injustiças ou das falhas cometidas contra indivíduos no passado, ora por particulares, ora pelo governo. O fundamento desse princípio é relativamente simples: quando uma parte lesiona a outra, tem o dever de reparar o dano, retornando a vítima à situação que se encontrava antes de sofrer a lesão. Propriamente dita, a teoria compensatória é a reivindicação para que se repare um dano ocorrido no passado em relação aos membros de determinado grupo minoritário.

Ver em: http://www.schwartzman.org.br/simon/adpf.pdf

${ }^{2}$ Adotamos o critério de pobreza do Ministério de Desenvolvimento Social e Combate à Fome, segundo o qual são considerados pobres os que possuem renda per capita entre $R \$ 70,00$ e $\mathrm{R} \$ 140,00$. A definição sofre contestações que consideraram que a linha de corte da renda deve se somar a outros critérios como as condições de moradia, o acesso à água, ao esgoto, à energia elétrica, aos documentos (déficit de direitos). Em geral, nossos respondentes também atendem essas condições de precariedade.

Ver em: http://www.mds.gov.br/programabolsafamilia/o_programa_bolsa_familia/o-que-e e http://www.ipea.gov.br/desafios/index.php?option=com_content\&view=article\&id=2579:catid=28 \&ltemid $=23$.
} 


\section{movimento \\ faculdade de educação - programa de pós-graduação em educação \\ universidade federal fluminense \\ issn 2359-3296 \\ ano 5 número 9 - 2018}

No Acre, apenas 5,83\% (IBGE, 2011) ${ }^{3}$ da população concluiu o ensino superior, ao passo que a média no Brasil o número é 8,31 (PNAD, 2012) ${ }^{4}$. 0 estado se encontra ainda mais distante das melhores estatísticas nacionais: São Paulo (11,67\%), Rio de Janeiro (10,91\%) e Paraná $(9,71 \%)$. Todas chegam ao dobro da acreana.

Com relação ao número de matrículas no ensino superior federal, no Acre, entre 2009 e 2013, houve um aumento de 35,7\%, passando de 9.827 para 15.284. De 2011 a 2012, houve um declínio de 12,38\%, diminuindo de 13.313 para 11.662. De acordo com os números do gráfico a seguir, o percentual de crescimento no estado ficou abaixo das médias da região Norte, a qual obteve um aumento de $49,7 \%$, bem como do Brasil que chegou a 40,9\% no período.

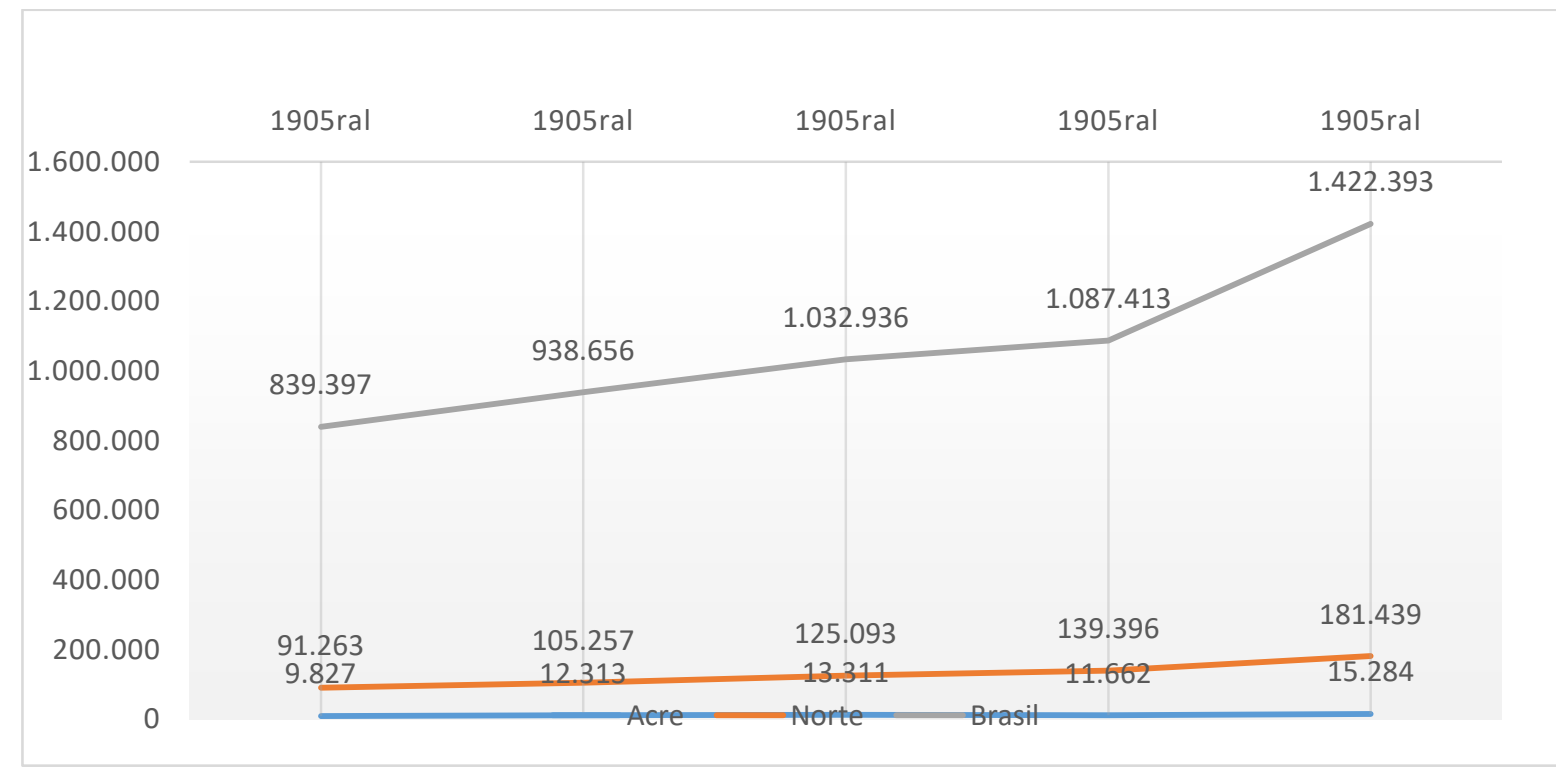

Gráfico 1: Matrícula Ensino Superior Federal no Brasil, Região Norte e Acre - 009/13. Fonte: Gráfico elaborado pela autora com base nos dados do Censo da Educação superior/INEP (2009-2013).

\footnotetext{
${ }^{3}$ Disponível em http://agazetadoacre.com/noticias/acre-e-o-4o-estado-da-regiao-norte-onde-aspessoas-mais-se-formam-no-nivel-superior/

Disponível em http://www.brasil.gov.br/educacao/2013/09/pnad-2012-cai-o-percentual-depessoas-sem-instrucao
} 


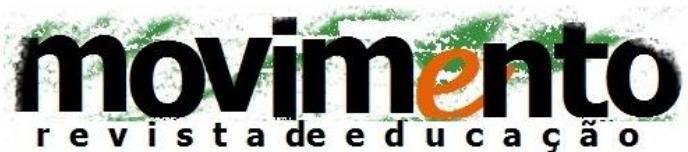 \\ faculdade de educação - programa de pós-graduação em educação \\ universidade federal fluminense \\ issn 2359-3296 \\ ano 5 número 9 - 2018}

A análise da presença de alunos pobres no ensino superior público federal do interior do estado do Acre traz como contribuição uma melhor compreensão das desigualdades relacionadas ao acesso. É a partir da problematização das transformações nas demandas e nas práticas escolares daqueles que dependem exclusivamente do sistema público para se beneficiar do processo de escolarização e, por meio dele, aumentar suas chances de inserção qualificada na vida social e no mundo do trabalho que podemos entender 0 processo.

Da mesma forma, ao refazer biografias escolares desses discentes que tiveram acesso aos cursos mais seletos da Universidade Federal do Acre, Campus Floresta, o estudo estará contribuindo com o esforço desenvolvido pelas pesquisas atuais (Souza e Silva, 2003; Nogueira, 1991; Viana, 1996; Portes, 2001; Zago, 2006; Salomon, 2001; Santo, 2001; Lages, 2001; e Pereira, 2005). Todas elas buscam conhecer como se constituem as trajetórias escolares longevas no seio das camadas populares.

Para alcançar o objetivo proposto, realizamos procedimentos de natureza quantitativa e qualitativa, operacionalizados em duas etapas. A primeira constituiu-se de uma descrição do perfil socioeconômico dos alunos pobres dos cursos mais seletivos - Enfermagem e Letras/Espanhol - da Universidade Federal do Acre, Campus Floresta, no período de 2009 a 2013, em que as políticas de ações afirmativas começaram a ser implementadas no Campus, e que, portanto, indicaria um maior aporte de alunos pobres na instituição. Chega-se aos sujeitos da pesquisa (alunos do Campus) via Pró-Reitoria de Assuntos Estudantis (PROAES). Ela concede a bolsa Pró-Estudo ${ }^{5}$ a discentes carentes. Nossos sujeitos de pesquisa são, portanto, esses bolsistas, não

\footnotetext{
${ }^{5}$ Programa que faz parte das políticas de permanência da UFAC. Será explicitado com mais detalhes no próximo capítulo.
} 


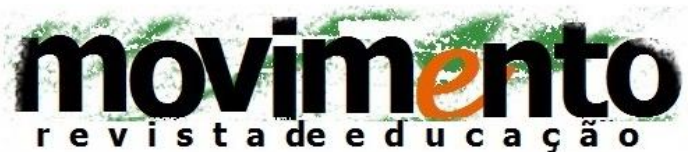 \\ faculdade de educação - programa de pós-graduação em educação \\ universidade federal fluminense \\ issn 2359-3296 \\ ano 5 número 9 - 2018}

ignorando que possa haver alunos pobres entre os não bolsistas, como poderá ser constatado mais adiante no texto.

O tratamento dos dados fornecidos pela PROAES objetiva caracterizar e analisar os perfis socioeconômicos desses estudantes nos últimos cinco anos (2009-2013), tomando como referência os questionários socioeconômicos utilizados pela UFAC para conceder a bolsa Pró-Estudo aos alunos pobres dos cursos de Enfermagem e Letras-Espanhol, habilitações mais concorridas dos últimos cinco anos (2009-2013). Esses dados serão apresentados em comparação aos de todo o universo do alunado desses cursos, segundo informações do ENADE.

A segunda etapa constituiu-se de entrevista semiestruturada com 6 alunos do curso de Letras-Espanhol e 4 de Enfermagem, selecionados a partir de 70 questionários disponibilizados pela PROAES. A princípio, como eram muitos questionários, decidimos selecionar cinco estudantes de cada curso a fim de aprofundarmos nossa compreensão sobre a temática pesquisada através das entrevistas.

Nesta pesquisa, utilizamos a lógica de Bourdieu. Para ele, o termo estratégia não deve ser visto como o produto inevitável de um cálculo custo-benefício, nem como mero resultado do acaso, mas fruto de decisões explícitas e racionais, decorrentes do processo de interiorização das regras do jogo social e reveladoras da intuição prática que marca o bom jogador, ou seja, o estrategista. Essa linha teórico-metodológica pareceu-nos mais adequada, uma vez que aponta para o aprofundamento em uma perspectiva sociológica à escala individual, permitindo, assim, a compreensão do social individualizado e buscando de maneira microssociológica analisar as trajetórias individuais e familiares 


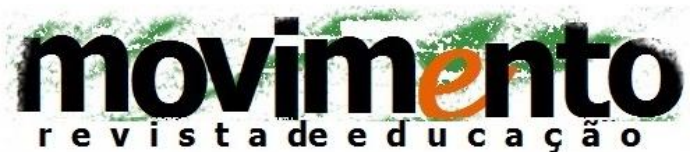 \\ faculdade de educação - programa de pós-graduação em educação \\ universidade federal fluminense \\ issn 2359-3296 \\ ano 5 número 9 - 2018}

utilizadas pelos acadêmicos para terem acesso e permanência à educação superior pública.

\section{Panorama do Ensino Superior no Brasil}

Nos últimos 40 anos têm ocorrido um intenso processo de massificação, contínua e sem precedente, da educação superior em todo o mundo. Passamos de 28.6 milhões de estudantes em 1970 a 100.8 milhões em 2007. Na América Latina, a taxa bruta de matrícula ascendeu de 6\% em 1970 para 23\% em 2000 e 34\% em 2007. Especificamente na Argentina, essa elevação foi de $53 \%$ para $67 \%$; na Colômbia, de $23 \%$ para $32 \%$; no Chile, de $37 \%$ para $52 \%$; no México, de $20 \%$ para $27 \%$ e, no Uruguai, de $34 \%$ para $64 \%$ (EZCURRA, 2011, apud VARGAS).

No período de 2003 a 2011, durante o mandato do presidente Luís Inácio Lula da Silva, foram nítidos os esforços do governo federal em agregar inclusão social e equidade em suas políticas destinadas à educação superior. Tal postura nasce com o intuito de amenizar o caráter predominantemente elitista que marca a história da universidade. Vale relembrar que o acesso era destinado, inicialmente, às elites dirigentes do país e aos seus filhos, excluindo mulheres, negros, índios e a camada popular. Ao longo do tempo, esses grupos foram lentamente conquistando esse espaço, apesar de ainda serem os discentes brancos e provenientes das camadas dominantes os que ocupam a maior parte das carteiras escolares.

Partido do pressuposto de que os governos de Fernando Henrique Cardoso e Luís Inácio Lula da Silva foram responsáveis por significativas alterações em nosso sistema de educação superior, o gráfico a seguir demonstra a evolução no número de matrículas em períodos marcantes na transição desses governos: 


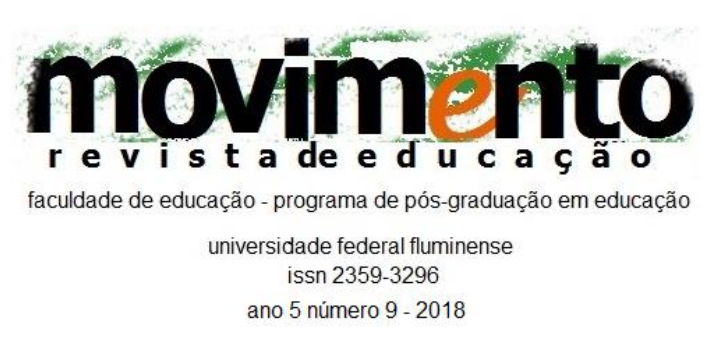

issn 2359-3296

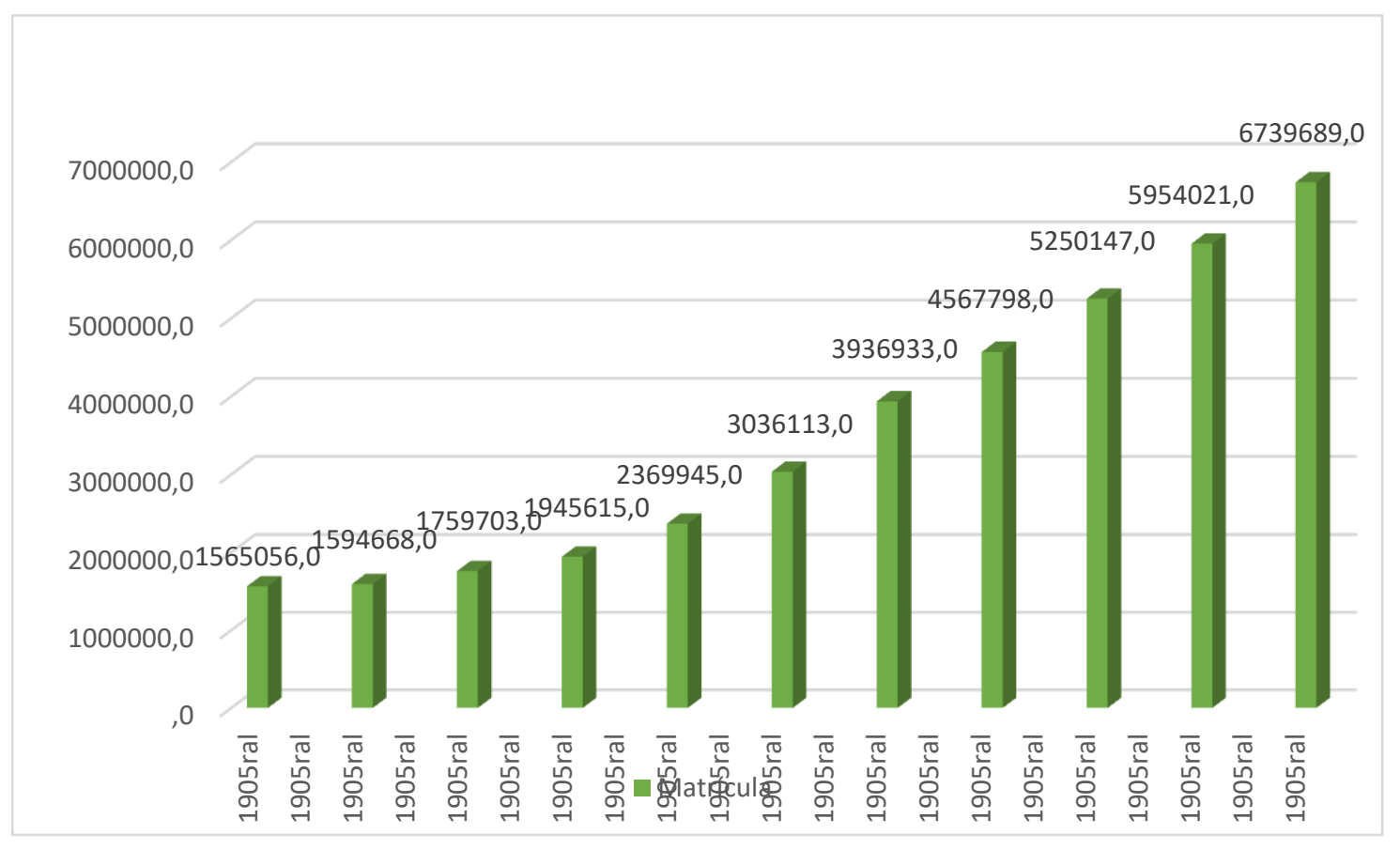

Gráfico 2: Evolução Total das Matrículas da Graduação no Brasil - (1991-2011). Fonte: INEP: 1991 a 2011.

Percebe-se que o nosso sistema de ensino superior até 2012 ainda era dominado pela elite. Apesar de ainda o ser, hoje estamos em processo de transição. Faz-se necessário evidenciar que essa mudança vem acontecendo principalmente através do aumento das instituições privadas sobre as matrículas na educação superior.

Apesar de encontrarmos características de elitismo perfazendo toda a história da educação superior brasileira, foi grande o esforço do governo anterior para 


\section{movimento \\ faculdade de educação - programa de pós-graduação em educação \\ universidade federal fluminense \\ issn 2359-3296 \\ ano 5 número 9 - 2018}

expandir e para democratizá-lo. É notório, entretanto, um número cada vez maior de jovens de diferentes perfis sociais chegando à universidade pela via de novas políticas de acesso. Atualmente, o maior desafio do governo tem sido a criação de mecanismos de permanência para garantir a consolidação dessa democratização.

\section{Um olhar sociológico sobre as oportunidades educacionais a partir da macro e da microsociologia e das suas respectivas influências na trajetória escolar dos indivíduos}

Uma das questões centrais da sociologia da educação de Bourdieu é a de que os alunos não são indivíduos que competem em condições de igualdade na escola, mas atores socialmente constituídos que trazem, em larga medida incorporada, uma bagagem social e cultural diferenciada e mais ou menos rentável no mercado escolar (BOURDIEU, 2014). Dessa forma, os diferentes níveis de prolongamento da escolarização conquistado pelos estudantes ao longo de seus percursos não poderiam ser explicados por seus dons pessoais, mas por sua origem social, que os colocaria em condições mais ou menos favoráveis diante das exigências escolares.

Segundo o autor, cada indivíduo passa a ser caracterizado por uma bagagem socialmente herdada. Essa bagagem inclui, por um lado, certos componentes externos a ele que podem contribuir para o prolongamento de sua escolarização. Esses elementos se constituiriam do capital econômico, referentes aos bens e aos serviços a que ele dá acesso. Isso é definido como capital social, ou seja, um conjunto de relacionamentos sociais influentes mantidos pela família. Além desse, haveria também o capital cultural institucionalizado, composto basicamente por títulos escolares. 


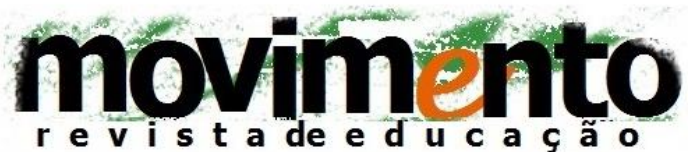 \\ faculdade de educação - programa de pós-graduação em educação \\ universidade federal fluminense \\ issn 2359-3296 \\ ano 5 número 9 - 2018}

Existem ainda os componentes objetivos, a saber, a bagagem transmitida pela família. Neles são disponibilizados certos artefatos aos indivíduos e que passam a fazer parte da subjetividade deles, sobretudo, o capital cultural na sua forma "incorporada".

Entre os elementos que compõem essa forma de capital, destacam-se a chamada "cultura geral" (os gostos em matéria de arte, culinária, decoração, vestuário, esportes e etc), o domínio maior ou menor da língua culta e o conhecimento sobre o universo escolar. É válido enfatizar que, para Bourdieu, o capital cultural constitui (sobretudo na sua forma incorporada) o componente da herança familiar que mais pesaria na definição do destino escolar. Isso porque a sua posse favoreceria o desempenho escolar na medida em que facilitaria a aprendizagem dos conteúdos e códigos.

O conceito de capital cultural foi criado para explicar as desigualdades em termos de prolongamento escolar segundo a classe social, rompendo com a ideia de que os indivíduos teriam aptidões intelectuais inatas. Assim, a diferença dos itinerários escolares se deve ao fato de famílias mais ricas terem maiores condições de investirem no processo de escolarização dos filhos do que as pobres. Dessa maneira, entendido como um dos elementos de uma bagagem socialmente herdada e que tem maior impacto na definição do destino escolar e sua reprodução dentro da própria instituição, o próprio capital cultural $^{6}$ faz com que as instituições escolares de maior prestígio continuem atendendo apenas a uma pequena fração da população como no passado.

Dessa maneira, cada grupo social, em função das condições objetivas que caracterizam sua posição na estrutura social, constituiria um sistema específico de disposições para a ação que seria transmitido aos indivíduos na forma do

\footnotetext{
${ }^{6}$ Alguns elementos constitutivos do capital cultural são a chamada cultura geral, o domínio maior ou menor da língua culta, o gosto e o "bom-gosto" (lazer, vestuário, esportes, paladar, etc.), as informações sobre o mundo escolar, entre outros (NOGUEIRA e NOGUEIRA, 2009).
} 


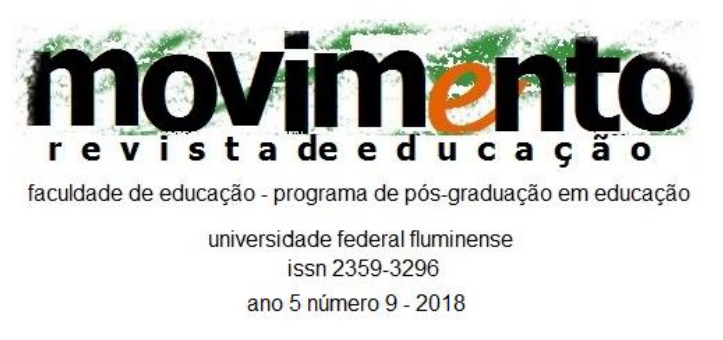

habitus. De acordo com Bourdieu (2011, p 84), o habitus é o "princípio gerador de estratégias objetivas, como consequências de práticas estruturadas que são orientadas por referência a funções objetivas". Podemos considerá-lo, então, como a ponte entre a estrutura e a prática ou entre as dimensões objetivas e subjetivas e as práticas sociais estruturadas a partir da posição social de quem as produz.

Bourdieu defende que, pelo acúmulo histórico de experiências de trajetórias escolares longas e de rupturas nesse processo, os grupos sociais iriam construindo um conhecimento prático (não plenamente consciente) alusivo ao que é possível ou não de ser conquistado por seus membros dentro da realidade social concreta da qual fazem parte e sobre as melhores formas de fazê-lo.

Ratificam a situação do quadro da educação brasileira de intenso processo de seletividade e exclusão os estudos desenvolvidos na tentativa de se compreender as estratégias que os pouquíssimos alunos negros e os de baixa renda utilizam para ingressar e para permanecer nos cursos superiores mais seletivos. A pesquisa de Setton (2005) confirma que esses estudantes pobres tendem a procurar os cursos de menor prestígio social, haja vista as escolhas de carreiras. Essa suposta decisão leva em consideração, na maioria das vezes, um conjunto de disposições que manifestam as estratificações advindas da maneira em que os diferentes capitais estão distribuídos.

Diante da problemática apresentada por Bourdieu envolvendo a inserção das camadas populares na educação, principalmente no ensino superior, alguns pesquisadores se propuseram enveredar por esse caminho e contribuir sobremaneira com estudos que evidenciam os percalços que assolam o êxito escolar das camadas populares. Entre eles, destaca-se o estudo de Alain 


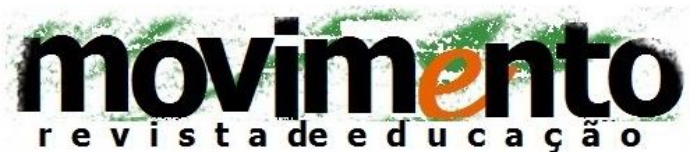 \\ faculdade de educação - programa de pós-graduação em educação \\ universidade federal fluminense \\ issn 2359-3296 \\ ano 5 número 9 - 2018}

Coulon, publicado no Brasil em 2008, intitulado "A condição de estudante: a entrada na vida universitária". Nesse livro, o autor evidencia que, apesar da evolução em termos do número de inscritos nas universidades francesas entre 1980 e 2000, as taxas de rupturas ao término do primeiro ano encontram-se muito elevadas: entre os anos de $2000-2001,57 \%$ dos estudantes repetiram, reorientaram-se ou abandonaram a universidade.

Assim como na França, também no Brasil as novas vias de acesso ao ensino superior têm aberto as portas das universidades a novas categorias de estudantes que as desconheciam. No entanto, como explicitado por Coulon, a democratização do acesso é importante, mas não é suficiente para assegurar a inclusão desses alunos. Para melhor entender essa questão, é válido relembrar que, segundo Bourdieu e Champagne (1997, p. 482):

O acesso ao ensino superior, de alunos pertencentes a famílias culturalmente desfavorecidas, apenas confirma a função conservadora da escola tida como libertadora e democrática, na medida em que o processo de eliminação foi adiado e diluído no tempo: e isso faz com que a instituição seja habitada a longo prazo por excluídos potenciais.

Em outra via, Dubet (2004), em sua obra "O que é uma escola justa", propõenos o desafio contemporâneo de compreender os problemas desencadeados pela atual escola democrática baseada nos princípios meritocráticos. ${ }^{7}$ Segundo o autor, embora ela tenha elevado o nível de escolarização de toda a população francesa e o número dos que terminaram o ensino médio tenha aumentado dez vezes nos últimos cinquenta anos, as diferenças não diminuíram ao longo desse tempo. Para ser justo, o modelo meritocrático de educação precisa oferecer igualdade de oportunidades, ignorando as desigualdades sociais dos alunos.

\footnotetext{
${ }^{7}$ Ao contrário das sociedades aristocráticas que priorizavam o nascimento e não o mérito, as democráticas escolheram o mérito como um princípio essencial de justiça: a escola é justa porque cada um pode obter sucesso nela em função de seu trabalho e de suas qualidades. (DUBET, 2004).
} 


\section{movimento \\ faculdade de educação - programa de pós-graduação em educação \\ universidade federal fluminense \\ issn 2359-3296 \\ ano 5 número 9 - 2018}

De qualquer forma, os autores aqui citados mostram, através de seus estudos, que as oportunidades educacionais são derivadas de atributos adquiridos socialmente. Afinal, a transmissão de vantagens e de desvantagens sociais acontece para além da herança econômica, carregando também as marcas das configurações e dos mecanismos sociais, o que torna o sistema escolar como uma caixa de ressonância das hierarquias sociais. (VARGAS, 2010).

Contrapondo tais estudos a uma perspectiva microssociológica, o trabalho de Bernard Lahire ressalta as limitações do conceito de habitus, especialmente, quando utilizado para a compreensão das ações de indivíduos específicos. Assim, indo além de Bourdieu, Lahire (1997, p.125) lança as bases, justamente, para uma sociologia em escala individual e observa que:

Os limites do conceito de habitus se revelam quando se passa do estudo de grandes categorias coletivas, como as classes sociais, para a análise do que ele chama de 'o social individualizado', ou seja, para a investigação do modo como indivíduos específicos lidam com múltiplas e, em parte, incoerentes influências sociais e as utilizam em suas ações práticas.

A análise torna-se muito mais complexa e a utilidade do conceito, menos evidente, quando o foco da investigação deixa de ser uma categoria coletiva e passa a ser, concretamente, o próprio indivíduo. A esse respeito, o autor tece a seguinte consideração:

Para compreender um indivíduo, é preciso saber quais são os desejos predominantes que ele aspira a satisfazer [...]. Mas estes desejos não estão inscritos nele antes de qualquer experiência. Constituem-se a partir de sua primeira infância sob o efeito da coexistência com os outros, e fixam-se progressivamente na forma que o curso de vida determinar, no correr dos anos, ou, às vezes, também de maneira brusca, após uma experiência particularmente marcante. (LAHIRE, 1997, p.18).

Dessa maneira, ao atribuir uma disposição a um indivíduo, determinam-se maneiras de ser, uma inclinação, uma tendência natural, um sentido, uma 


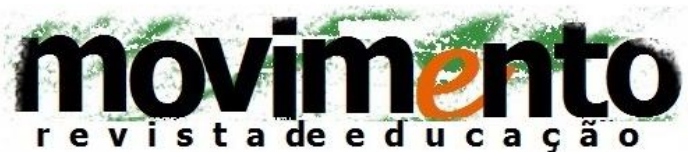 \\ faculdade de educação - programa de pós-graduação em educação \\ universidade federal fluminense \\ issn 2359-3296 \\ ano 5 número 9 - 2018}

possibilidade de que ele venha a agir (pensar, sentir) de certo modo, em certas condições.

A sociologia dos indivíduos fornece suporte para uma da educação interessada pelo estatisticamente "improvável", deslocando-se o olhar sociológico das macroestruturas, das grandes regularidades, para as microestruturas e para as pequenas unidades de análise (FORQUIN, 1995).

Assim, se os estudos macrossociológicos sobre as desigualdades escolares demonstram uma forte correlação estatística entre a origem social dos alunos e seu rendimento escolar e "apresentam as crianças dos meios populares como sendo atingidas 'de forma muito mais maciça e regular' por situações de fracasso" (FORQUIN, 1995, p.81), atualmente tem se procurado analisar com mais detalhes o papel do pertencimento social nos destinos escolares, dando maior visibilidade às práticas educativas desenvolvidas no interior das famílias, à complexa relação entre família e escola e às estratégias familiares e individuais relativas à escolarização (pressupondo uma relativa autonomia entre essas duas esferas).

Passemos a examinar agora o nosso campo empírico: a UFAC, campus Floresta, e o alunado de baixa renda nos cursos mais seletivos.

\section{Comparação entre o perfil socioeconômico dos alunos bolsistas e do grupo de estudantes de Enfermagem e Letras-Espanhol}

Antes de passarmos ao exame mais minucioso do perfil dos estudantes bolsistas de Letras e de Enfermagem, trazemos um comparativo entre alguns marcadores socioeconômicos dos bolsistas e do grupo geral. A instituição não dispõe de dados próprios sobre todos os discentes, apenas dos bolsistas. 


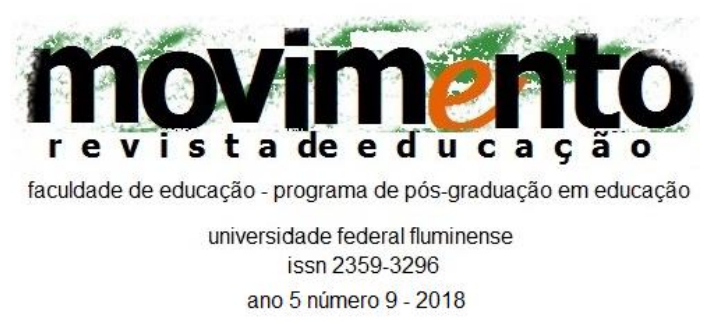

Assim sendo, retiramos do questionário socioeconômico do Enade dos anos de 2011 e de 2013 essas informações, com a ressalva que o subconjunto dos bolsistas está presente na caracterização. $O$ curso de Letras participou do Enade 2011 e o de Enfermagem, em 2013.

\begin{tabular}{|c|c|c|c|c|}
\hline & \multicolumn{2}{|c|}{ ENFERMAGEM } & \multicolumn{2}{|c|}{ LETRAS } \\
\hline & Bolsistas & Não bolsistas & Bolsistas & Não bolsistas \\
\hline $\begin{array}{c}\text { Cor } \\
\text { predominante }\end{array}$ & Pardo & Pardo & Pardo & Pardo \\
\hline $\begin{array}{l}\text { Renda } \\
\text { Familiar }\end{array}$ & $\begin{array}{l}\text { Até } 1 \text { salário } \\
\text { mínimo }\end{array}$ & $\begin{array}{l}3 \text { a } 10 \text { salários } \\
\text { mínimos }\end{array}$ & $\begin{array}{l}\text { Até } 1 \text { salário } \\
\text { mínimo }\end{array}$ & $\begin{array}{l}1,5 \text { a } 3 \text { salários } \\
\text { mínimos }\end{array}$ \\
\hline $\begin{array}{c}\text { Escolaridade } \\
\text { Pai }\end{array}$ & $\begin{array}{l}\text { Ensino } \\
\text { Fundamental } \\
\text { Incompleto }\end{array}$ & $\begin{array}{l}\text { Inferior ao } \\
\text { Ensino } \\
\text { Superior }\end{array}$ & $\begin{array}{c}\text { Ensino } \\
\text { Fundamental }\end{array}$ & $\begin{array}{c}\text { Inferior ao Ensino } \\
\text { uperior }\end{array}$ \\
\hline $\begin{array}{c}\text { Escolaridade } \\
\text { Mãe }\end{array}$ & $\begin{array}{c}\text { Ensino } \\
\text { Fundamental }\end{array}$ & Ensino Médio & $\begin{array}{c}\text { Ensino } \\
\text { Fundamental }\end{array}$ & $\begin{array}{c}\text { Inferior ao Ensino } \\
\text { Superior }\end{array}$ \\
\hline $\begin{array}{c}\text { Tipo de } \\
\text { escola que } \\
\text { fez o Ensino } \\
\text { Médio }\end{array}$ & Pública & Pública & Pública & Pública \\
\hline $\begin{array}{l}\text { Renda do } \\
\text { Aluno }\end{array}$ & Sem renda & Sem renda & Com renda ${ }^{8}$ & Sem renda \\
\hline
\end{tabular}

De acordo com o quadro acima, notamos uma grande similaridade no perfil socioeconômico tanto dos bolsistas quanto dos não bolsistas de ambos os cursos pesquisados: a maioria dos estudantes são pardos e a maioria dos bolsistas com renda de até 1 salário mínimo. Os alunos que não possuem a bolsa Pró-Estudo têm renda familiar entre 1,5 e 3 salários mínimos. No que diz respeito ao grau de escolaridade dos pais e das mães dos alunos bolsistas, prevaleceu o ensino fundamental. Vale ainda ressaltar que a maioria dos discentes estudou em escola pública e poucos deles trabalham, sendo que apenas alguns bolsistas exercem algum tipo de atividade remunerada, mas

\footnotetext{
${ }^{8}$ Os alunos trabalham, mas ganham muito pouco pelos serviços prestados, tendo que contar com ajuda de familiares e /ou outras pessoas para custearem seus estudos.
} 


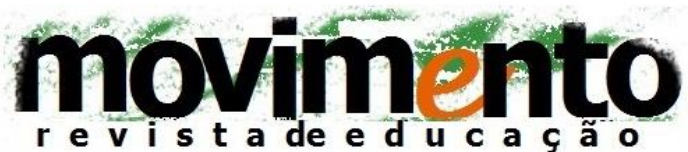 \\ faculdade de educação - programa de pós-graduação em educação \\ universidade federal fluminense \\ issn 2359-3296 \\ ano 5 número 9 - 2018}

mesmo assim, ainda necessitam da ajuda da família e/ou das outras pessoas para custearem seus estudos.

Passando agora à análise do perfil socioeconômico dos bolsistas dos cursos pesquisados, valemo-nos dos questionários aplicados pela Proaes para concessão de bolsas. Dentre outros indicadores, esse questionário indaga sobre cor/raça, moradia, tipo de transporte para chegar à universidade, ensino médio (público ou privado), se já possui graduação, como foi o ingresso na universidade (vestibular, transferência etc.), situação de trabalho, escolaridade dos pais e a renda familiar.

Em todos os anos analisados, um total de 52 alunos de Letras-Espanhol e 18 de Enfermagem foram contemplados com a bolsa. Desse total, 8 estudantes de Letras e 10 de Enfermagem a receberam por mais de um semestre durante esse período. Sendo poucos os contemplados ano a ano, e não havendo maiores modificações no perfil socioeconômico no período analisado, não extraímos os percentuais de cada variável e optamos por transcrever a característica predominante ano a ano.

Os dados nos permitem perceber que, durante os anos pesquisados (20092013), houve predomínio de alunos autodeclarados pardos contemplados com a bolsa Pró-Estudo em ambos os cursos, aparecendo apenas quatro estudantes negros. Com relação à escolaridade dos pais, há um predomínio do ensino fundamental incompleto, com apenas quatro casos de fundamental completo. Em se tratando das mães, o grau de escolaridade permanece o mesmo, diferindo apenas que o ensino fundamental completo é o que prevalece entre elas. Destaquemos, porém, os pais analfabetos dos alunos de Enfermagem. É pertinente salientar, ainda, que, nos anos de 2011 e 2012, os questionários socioeconômicos utilizados pelo programa Pró-Estudo não dispunham dessa pergunta, deixando-nos sem análise das informações 


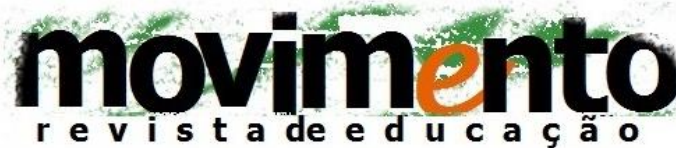 \\ faculdade de educação - programa de pós-graduação em educação \\ universidade federal fluminense \\ issn 2359-3296 \\ ano 5 número 9 - 2018}

referentes à escolaridade dos pais e das mães durante esse intervalo de tempo. Com relação à remuneração, há um predomínio considerável de alunos que não trabalham e que vivem, juntamente com seus pais e irmãos, com uma renda familiar de até 1 salário mínimo.

\section{Alunos pobres de Letras-Espanhol e de Enfermagem: família, percurso escolar, acesso e permanência}

Conforme exposto anteriormente, por meio dos questionários de inscrição da bolsa Pró-Estudo, selecionamos 5 alunos de Enfermagem e 5 de LetrasEspanhol para serem submetidos a uma entrevista de análise de seus percursos escolares e de seus familiares ${ }^{9}$. Um dos discentes de Enfermagem não chegou para o momento da entrevista e não conseguirmos mais contato posteriormente. Procuramos diversificar os períodos em que os estudantes cursavam para ampliarmos nossa visão longitudinal do processo de acesso e de permanência. Tivemos como objetivo investigar a escolarização dos entrevistados e de seus familiares, em uma escuta que busca reconstituir os traços desses percursos, as suas condições e as expectativas parentais relacionadas à escolarização dos filhos. Nesse sentido, indagamos também acerca da escolarização dos irmãos de nossos participantes, procurando maior amplitude na compreensão das condições gerais da realidade das famílias dos entrevistados. Para Lahire (1997, p. 17)

A criança constitui seus esquemas comportamentais, cognitivos e de avaliação através das formas que assumem as relações de interdependência com as pessoas que a cercam com mais frequência e por mais tempo, ou seja, os membros de sua família.

\footnotetext{
${ }^{9}$ Ao todo foram analisados 70 questionários, sendo 52 do curso de Letras-Espanhol e 18 de Enfermagem. Em cada semestre, o primeiro disponibiliza 50 vagas e o segundo, 30 .
} 


\section{movimento \\ faculdade de educação - programa de pós-graduação em educação \\ universidade federal fluminense \\ issn 2359-3296 \\ ano 5 número 9 - 2018}

Tal acontecimento não assegura que uma pessoa reproduza as formas de agir de sua família. No entanto, ela encontra uma maneira de comportar-se baseada nas "configurações das relações de interdependência" (LAHIRE, 1997) do grupo no qual está inserida. Dessa maneira, concebemos que o sucesso escolar esteja ligado fundamentalmente às práticas escolares familiares que cada uma dessas famílias desenvolve em seu meio. Neste estudo especificamente, estamos analisando um grupo de pessoas que alcançou uma trajetória escolar longa ao transcender as barreiras do ensino superior. Acerca do tema, Lahire (1997, p.256) assegura:

[...] supomos, às vezes, que é no grau de conscientização e de mobilização familiares em relação aos desafios escolares que reside o princípio das diferenças entre as escolaridades de meios populares [...] A rentabilidade escolar dos comportamentos de investimento varia conforme a configuração familiar considerada.

Dessa maneira, analisamos as características gerais dos sujeitos pesquisados, o capital escolar de seus familiares, incluindo avós, pais e irmãos, bem como as suas estratégias pessoais e familiares para superarem as grandes dificuldades que tiveram para ascender ao nível superior. Conhecer as condições de trabalho de seus genitores e as estratégias de investimento escolar utilizadas também se configuraram em informações relevantes para a nossa pesquisa. Além disso, analisamos as trajetórias escolares dos discentes no ensino superior.

Inicialmente, apresentamos um perfil resumido dos entrevistados com relação a características pessoais e familiares de interesse. Vale ressaltar a utilização de nomes fictícios, a fim de preservar o anonimato deles.

\begin{tabular}{|c|c|c|c|c|c|c|c|c|c|}
\hline Nome & Idad & Pele & $\begin{array}{c}\text { Estado } \\
\text { - Civil }\end{array}$ & $\begin{array}{c}\text { Origem } \\
\text { geográfica } \\
\text { familiar }\end{array}$ & $\begin{array}{c}\text { Município } \\
\text { em que } \\
\text { residem }\end{array}$ & Curso & $\begin{array}{c}\text { Trabalho/ } \\
\text { Estudo }\end{array}$ & Irmãos & $\begin{array}{c}\text { Irmãos } \\
\text { universi } \\
\text { tários }\end{array}$ \\
\hline
\end{tabular}




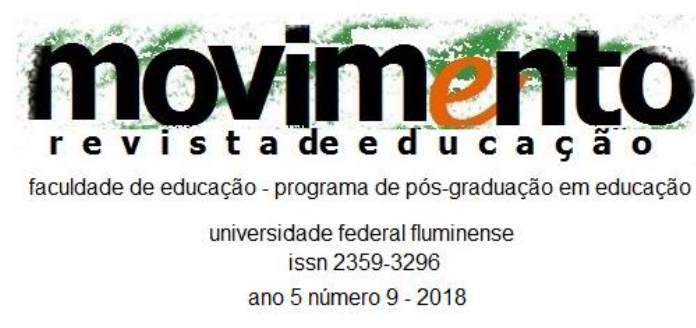

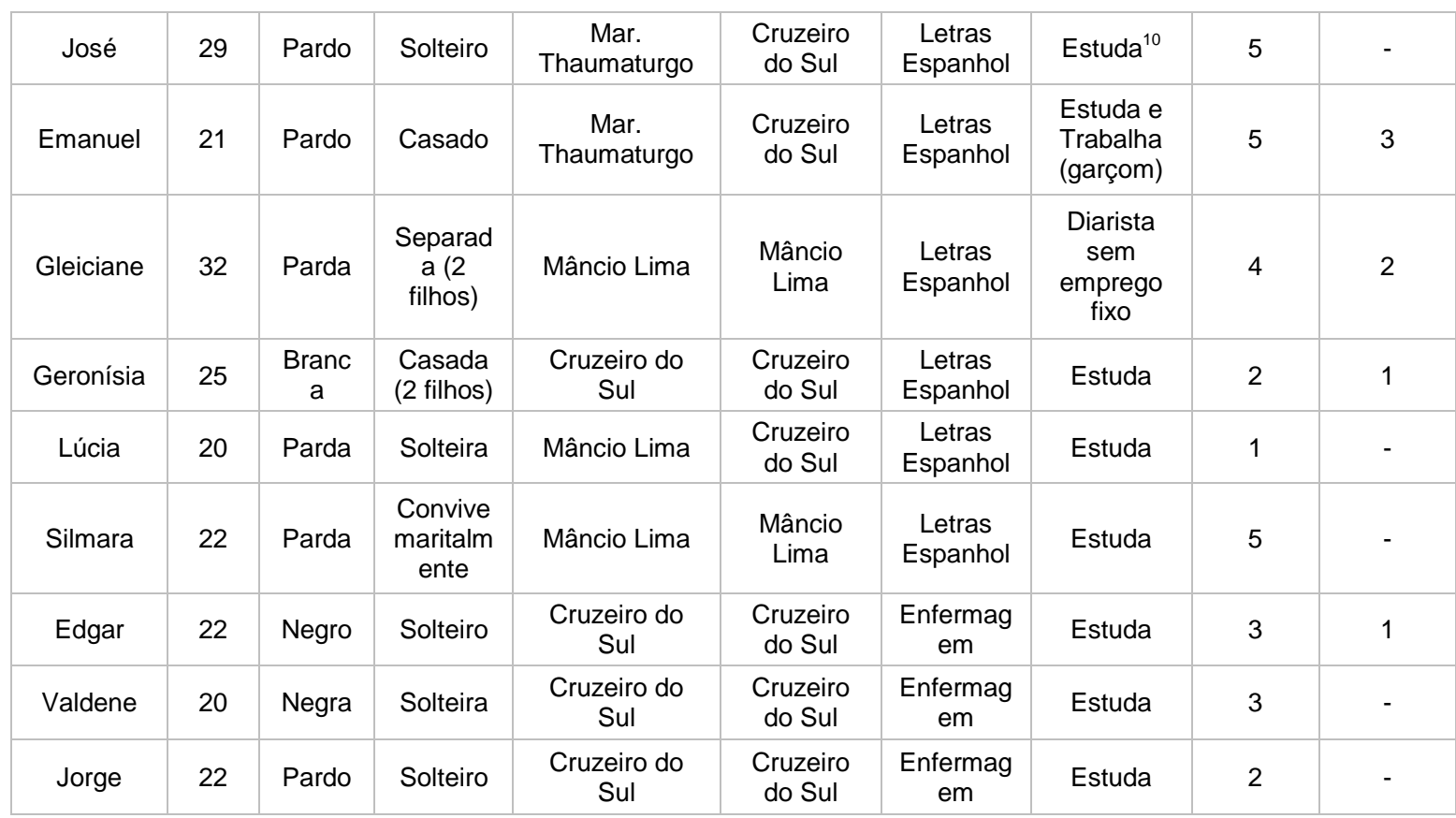

Tabela 2: Resumo perfil dos estudantes entrevistados. Fonte: Quadro elaborado pela autora com base em dados da pesquisa

Dos 10 alunos entrevistados, 5 são mulheres, com idade variando entre $20 \mathrm{e}$ 32 anos, O mais jovem tinha 19 anos em 2013. Todos são naturais do estado do Acre, sendo 4 do município de Cruzeiro do Sul, 3 de Mâncio Lima, 2 de Marechal Thaumaturgo e 1 de Tarauacá. Dos entrevistados de Mâncio Lima, um mora na casa do estudante da UFAC em Cruzeiro do Sul e os outros dois precisam deslocar-se diariamente de seu município, a cerca de $43 \mathrm{~km}$ de distância, sem condução própria e ainda estão tentando conseguir o Auxílio Estudantil (no valor de $\mathrm{R} \$ 100,00$ ) para Deslocamento Intermunicipal.

Os estudantes oriundos dos outros municípios tiveram de mudar-se para Cruzeiro do Sul para cursar o ensino superior, já que seus municípios são distantes e de difícil acesso. Mesmo com pouca idade, 1 já está casado oficialmente, 1 convive maritalmente com o companheiro (a) e a entrevistada

\footnotetext{
${ }^{10}$ Perdeu o emprego em novembro de 2014, pois ocupava um cargo com indicação política na Secretaria de Esportes da Prefeitura Municipal
} 


\section{movimento \\ faculdade de educação - programa de pós-graduação em educação \\ universidade federal fluminense \\ issn 2359-3296 \\ ano 5 número 9 - 2018}

de maior idade de todos, com 32 anos de idade, já viveu a experiência da separação conjugal.

Com relação à categoria trabalho, apenas 2 dos alunos pesquisados afirmaram estudar e trabalhar. Ressaltamos que todos os 4 de Enfermagem justificam o fato de não poderem trabalhar devido ao turno integral (tarde e noite). Os discentes que trabalham desempenham as funções de garçom e faxineira.

\section{As condições de trabalho dos familiares}

A abordagem das condições de trabalho dos pais de nossos entrevistados torna-se necessária como mais uma forma de compreender as condições de vida durante a trajetória escolar dos estudantes. A aproximação com esse universo contribui para nossa compreensão acerca das estratégias familiares adotadas para o prolongamento escolar dos filhos.

\begin{tabular}{|c|c|c|}
\hline Categorias & Ocupações & N \\
\hline Trabalhadores rurais & Agricultor & 2 \\
\hline Trabalhadores Autônomos & $\begin{array}{c}\text { Vendedor (1) } \\
\text { Pescador (1) }\end{array}$ & 1 \\
\hline Trabalhadores não \\
qualificados & Auxiliar de serviços & 1 \\
\hline gerais & 1 \\
\hline Trabalhadores da Educação & $\begin{array}{c}\text { Professor de Educação } \\
\text { Básica }\end{array}$ & 1 \\
\hline Desempregado & - & 2 \\
\hline Sem resposta & - & 9 \\
\hline Total & - & 2 \\
\hline
\end{tabular}

Tabela 3: Categorias socioprofissionais ${ }^{11}$ dos pais dos entrevistados. Fonte: Tabela elaborada pela autora com base em dados da pesquisa.

De forma geral, percebemos nessa categorização socioprofissional que os filhos investigados são provenientes de pais que exercem funções de baixa

\footnotetext{
${ }^{11}$ As categorias socioprofissionais foram tomadas como referência a partir dos estudos de Portes (1993).
} 


\section{movimento \\ faculdade de educação - programa de pós-graduação em educação \\ universidade federal fluminense \\ issn 2359-3296 \\ ano 5 número 9 - 2018}

remuneração e em áreas que não exigem nível superior, haja vista que apenas um dos genitores atingiu esse patamar educacional (formado em Letras e em Pedagogia).

As mães dos entrevistados, em sua maioria, não possuem atividade remunerada fora do lar, que mesmo em número menor que as avós, ainda representam a maioria de $40 \%$ do total de mães "trabalhadoras do lar", conforme a Tabela que se segue.

\begin{tabular}{|l|c|c|}
\hline \multicolumn{1}{|c|}{ Categorias } & $\begin{array}{c}\text { Ocupações } \\
\text { Do Lar }\end{array}$ & Nrabalho doméstico \\
\hline $\begin{array}{l}\text { Trabalhadoras manuais } \\
\text { semiqualificadas no serviço } \\
\text { doméstico }\end{array}$ & $\begin{array}{c}\text { Auxiliar de serviços gerais na } \\
\text { escola }\end{array}$ & 4 \\
\hline $\begin{array}{l}\text { Aposentada } \\
\text { Empregadas domésticas }\end{array}$ & 3 \\
\hline $\begin{array}{l}\text { Trabalhadoras } \\
\text { semiqualificadas alocadas } \\
\text { na indústria }\end{array}$ & Aposentada por invalidez & 1 \\
\hline Sem resposta & Empresa Colgate & 1 \\
\hline Total & - & 1 \\
\hline
\end{tabular}

Tabela 4: Categorias socioprofissionais das mães dos entrevistados. Fonte: Quadro elaborado pela autora com base nos dados da entrevista

Por disponibilizarem "mais tempo" em casa, dedicadas apenas às atividades domésticas, pode-se supor que a maioria das mães dos alunos entrevistados se ocupassem, de uma forma ou de outra, da escolarização dos filhos. Por isso, tomamos como investigação o capital escolar delas para compreendermos a contribuição da sua escolarização na ajuda aos filhos, dentro da perspectiva de análise colocada por Lahire (1997) de que não basta a posse de um capital escolar, é preciso que ele esteja à disposição da criança e teça uma função pedagógica efetiva.

\section{Capital escolar dos familiares dos alunos dos cursos de Enfermagem e de Letras-Espanhol}

\footnotetext{
${ }^{12}$ A filha não soube informar qual a ocupação da mãe nessa empresa, pois, há muitos anos, elas não se falam, (pais separados) mas, por ter o ensino médio incompleto, sugere-se que a mãe ocupe a categoria socioprofissional acima mencionada.
} 


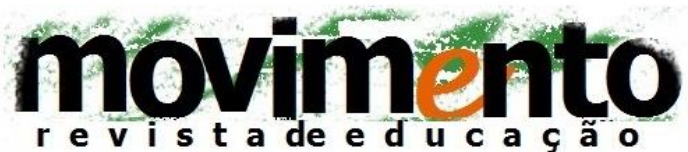 \\ faculdade de educação - programa de pós-graduação em educação \\ universidade federal fluminense \\ issn 2359-3296 \\ ano 5 número 9 - 2018}

A investigação do grau de escolaridade dos familiares dos alunos pesquisados revelou um fraco capital escolar ${ }^{13}$ atingido pelas famílias dos entrevistados, principalmente no que se refere aos seus avós.

Analisando a escolarização dos avós paternos e dos maternos dos 10 alunos entrevistados, percebe-se que do total de 40, 24 têm escolaridade desconhecida por seus netos, sendo a falta de conhecimento sobre os estudos dos avós paternos maior do que a dos maternos. Tais dados não deixam de explicitar o predomínio do analfabetismo entre eles: 9 dos 16 não sabem ler nem escrever, sendo desses, quatro avôs e cinco avós.

O prosseguimento nos estudos, superior às séries iniciais, era algo ainda muito raro, devido às dificuldades de acesso ao ensino e ao trabalho iniciado precocemente (principalmente no meio rural, onde viviam os avós de 4 dos 10 entrevistados). Com base nesses dados, evidenciou-se um baixo capital escolar dos avós que pudesse ficar como herança cultural para os filhos, intensificando a taxa de $24,5 \%$ de analfabetos no estado do Acre.

Dos 7 avós tidos como alfabetizados por seus netos, 2 deles conseguem ler com dificuldades e não se sabe até que série inicial do ensino fundamental eles tinham estudado. Os outros 5 alfabetizados chegaram a estudar até a $4^{\mathrm{a}}$ série do ensino fundamental não tendo nenhum deles avançado para as séries finais. Quando questionados sobre a convivência com os avós, a maioria dos pesquisados afirmou não ter convivido e alguns nem chegaram a conhecê-los.

\section{A escolaridade da geração dos pais dos entrevistados}

${ }^{13}$ O termo capital escolar é entendido, de acordo com Pierre Bourdieu, como uma das variações do termo capital cultural, em seu estado institucionalizado, como a acumulação de títulos escolares. 


\section{movimento \\ faculdade de educação - programa de pós-graduação em educação \\ universidade federal fluminense \\ issn 2359-3296 \\ ano 5 número 9 - 2018}

Diferente dos avós, que não chegaram sequer a cursar as séries finais do ensino fundamental pelo menos 1 das 10 mães e 1 dos 10 pais dos entrevistados conseguiram não só ingressar, mas concluir o ensino superior (ela é formada em Letras-Português e ele, em Pedagogia). Trata-se não apenas de um avanço significativo na evolução da escolaridade dos antecedentes dos alunos pesquisados, como um aumento considerável do tempo de estudo das mães.

Enquanto 1 dos pais é analfabeto e 1 não concluiu as séries iniciais do ensino fundamental, todas as mães são alfabetizadas e 2 concluíram o ensino médio, Apenas 1 dos pais conseguiu fazê-lo. Nessa geração, portanto, já percebemos um crescimento do capital cultural feminino em relação ao masculino, fenômeno que não acontecia com os avós. Na escolaridade brasileira, as mulheres têm maior escolaridade do que os homens. O Censo da Educação Superior do ano de 2010 demonstrou que, dentre os concluintes do ensino superior, 60,9\% deles são do sexo feminino (INEP, 2011, p. 15).

Nesse caso, um nível maior de capital escolar, sobretudo das mães dos entrevistados, poderia ter sua contribuição para a longa trajetória dos filhos. Não raras vezes responsabilizadas quase que exclusivamente pela tarefa de educação escolar dos filhos, elas poderiam contribuir positivamente para a longevidade escolar de sua prole. Foi verificado que a frequência nas reuniões escolares e o incentivo para estudar e poder usufruir de uma vida melhor eram de responsabilidade feminina nos lares: 7 dos 9 entrevistados afirmaram que isso era atribuições prioritariamente maternas durante suas trajetórias escolares na educação básica. 


\section{$\underset{r e v i s t a d e d u c i c s}{\operatorname{movim}}$ \\ faculdade de educação - programa de pós-graduação em educação \\ universidade federal fluminense \\ issn 2359-3296 \\ ano 5 número 9 - 2018}

Tal evidência é corroborada pelos estudos de Portes (1993) que ressaltam as atividades estratégicas desenvolvidas pelas mães dos seus entrevistados como

A busca do estabelecimento escolar, o incentivo e auxílio a aprendizagem escolar, os cuidados (físicos e materiais) necessários a manutenção dos filhos na casa e no estabelecimento escolar - e a busca constante de uma relação de proximidade junto à escola, mesmo diante das dificuldades econômicas e culturais para desempenhá-las. (PORTES, 1993, p. 162).

Diferentemente dos pais, nenhum dos 22 irmãos dos entrevistados são analfabetos ou possuem apenas as séries iniciais do ensino fundamental. Apenas 2 deles não terminaram o ensino fundamental, 31,81\% concluíram o ensino médio e $18,1 \%$ deles dividem-se igualmente entre alunos que estão cursando o ensino superior ou que já o concluíram.

Assim, fica evidente que as políticas e os programas federais para acesso aos níveis superiores da educação estão funcionando. Além disso, o fato de alguns dos avós e de alguns pais dos alunos pesquisados que moravam na zona rural de alguns municípios acreanos terem migrado para a urbana para melhor atenderem às necessidades de escolarização de suas proles, ajuda a explicar esse processo de evolução do perfil de escolarização das famílias dos alunos pesquisados.

Se avaliarmos a escolaridade no período dessas três gerações, podemos encontrar resultados como os evidenciados no gráfico que segue. 

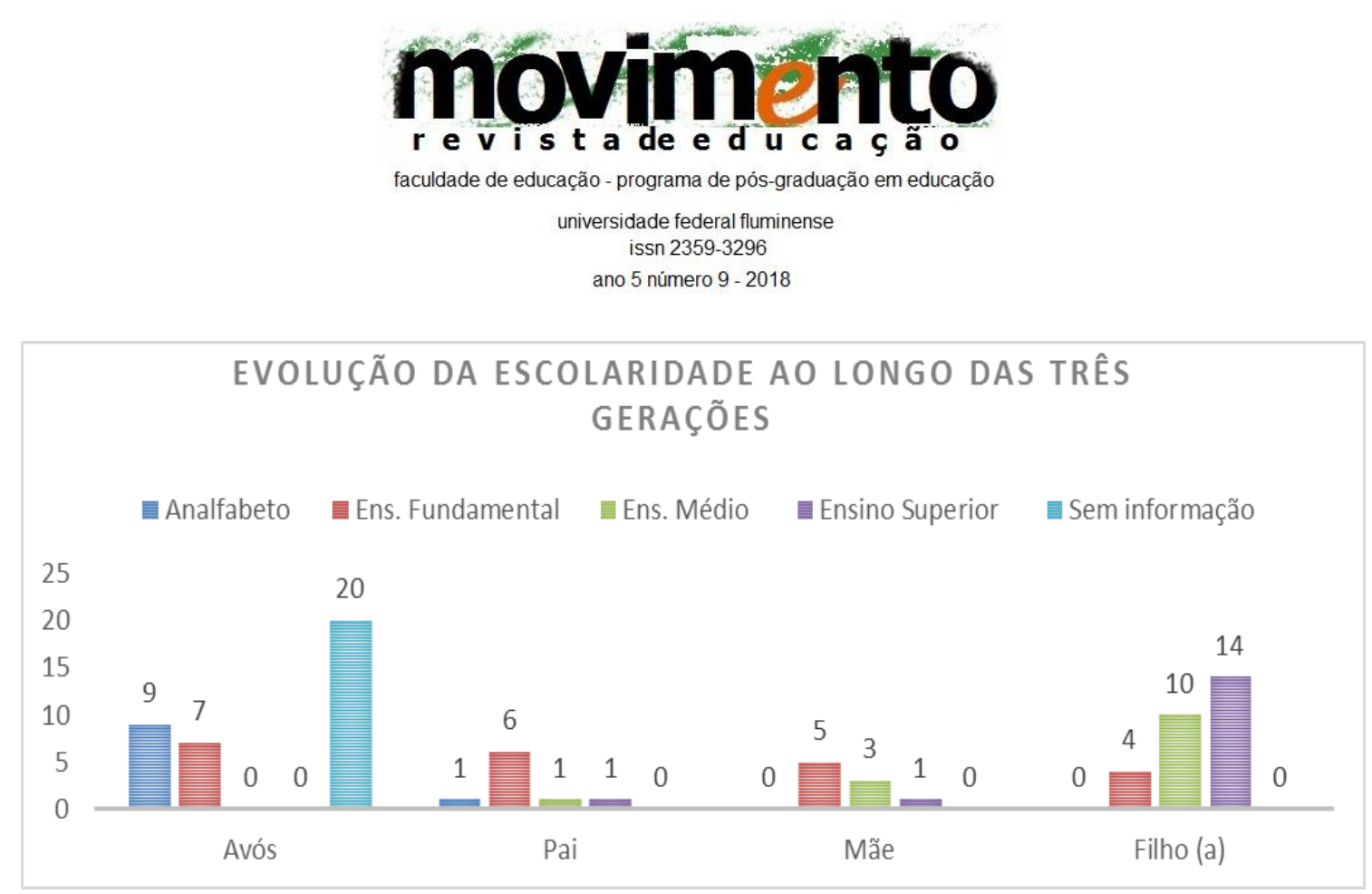

Gráfico 3: Evolução da escolaridade ao longo das três gerações. Fonte: Gráfico elaborado pela autora com base nos dados da pesquisa

Esse aumento na escolaridade tem reflexos nacionalmente. Várias pesquisas feitas atualmente demonstraram que, na geração atual, os filhos já estão superando o grau de escolaridade dos pais.

\section{Investimentos escolares: estratégias familiares em contexto amazônico}

O prolongamento escolar dos alunos pesquisados pode ser certamente atribuído a pelo menos duas condições decisivas. A primeira diz respeito à participação da família na execução de projetos de escolarização prolongada para seus filhos e na manutenção deles no que diz respeito ao comportamento e estratégias. A segunda é um superinvestimento familiar e do próprio filho na causa escolar.

Nesse sentido, os dados confirmam claramente os aspectos objetivos e subjetivos envolvidos na questão, conciliando esses extremos, como nos ensinam Bourdieu e Lahire (BOURDIEU, 2002; LAHIRE, 2006). Por exemplo: torna-se impossível cogitar as trajetórias escolares longevas desses jovens, para além das circunstâncias já destacadas, sem as relacionar com a imagem 


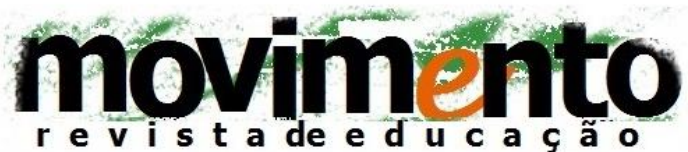 \\ faculdade de educação - programa de pós-graduação em educação \\ universidade federal fluminense \\ issn 2359-3296 \\ ano 5 número 9 - 2018}

altamente positiva que eles têm de si nesse percurso. Ao solicitarmos aos 10 entrevistados que falassem sobre a sua atuação enquanto alunos, 8 deles apoiaram-se em termos positivos como "comprometido", "disciplinado", "interessado", "responsável", "dedicado", entre outros.

Todos os pais dos alunos entrevistados veem a escola como prioridade em casa e como algo que possui um valor extremamente significativo e uma chance de "construir um futuro melhor" para os filhos. Por isso, mesmo a maioria tendo baixa escolaridade, empenhavam-se bastante em incentivar e proporcionar condições para que os seus filhos pudessem estudar.

A maior parte das mães se ocupam dos trabalhos nos próprios lares: 3 delas possuem menos que 4 anos de escolaridade e não concluíram sequer as 4 séries iniciais do ensino fundamental. Esse dado nos faz supor, portanto, que nenhuma delas, caracterizadas como "trabalhadoras do Lar", teve um nível de capital escolar que pudesse contribuir para influenciar positivamente em uma longa trajetória escolar de sua prole. Em contrapartida, elas conseguiram desenvolver estratégias de supervisão, de incentivo e de preocupação com o estudo dos filhos. Esses mecanismos são considerados por todas as famílias analisadas como sendo o único capaz de proporcionar um futuro melhor para os filhos. Tal evidência é corroborada pelos estudos de Portes (1993) que ressalta as atividades estratégicas desenvolvidas pelas mães dos seus entrevistados como

A busca do estabelecimento escolar, o incentivo e auxílio a aprendizagem escolar, os cuidados (físicos e materiais) necessários a manutenção dos filhos na casa e no estabelecimento escolar - e a busca constante de uma relação de proximidade junto à escola, mesmo diante das dificuldades econômicas e culturais para desempenhá-las. (PORTES, 1993, p. 162). 


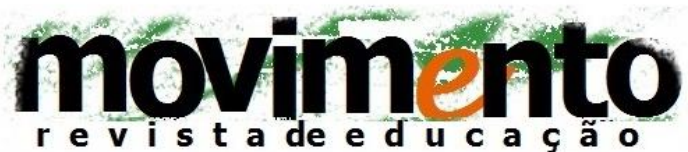 \\ faculdade de educação - programa de pós-graduação em educação \\ universidade federal fluminense \\ issn 2359-3296 \\ ano 5 número 9 - 2018}

Portanto, em nossa pesquisa, o processo de escolarização dos filhos apresentou-se como um importante investimento dentro do amplo projeto familiar de ascensão social, ocasionando no processo de migração da zona rural para a urbana. Assim, em vez de desenvolverem uma atitude de passividade diante das dificuldades de escolarização impostas pelo meio em que viviam, essas famílias desenvolveram estratégias para gerenciar os contratempos.

A pesquisa reforça também a contribuição de alguns professores no que diz respeito ao incentivo e à criação de estratégias de favorecimento ao prolongamento escolar dos alunos pesquisados. Nas falas dos estudantes, permeiam representações de que o bom docente é aquele que prepara para os exames vestibulares, monta aulas dinâmicas e que incentiva para o ingresso na universidade, sugerindo que a busca pelo ensino superior tem sido uma constante nas redes de sociabilidade em que convivem esses discentes.

Discutem-se a seguir as estratégias na própria trajetória escolar dos entrevistados que tenham possibilitado a chegada ao ensino superior em um meio em que as probabilidades estatísticas se apresentavam tão reduzidas.

\section{As relações com o ensino superior: acesso e permanência}

A escolha do curso superior é um grande dilema que aflige muitos jovens no momento de inscrição em exames vestibulares. Essa escolha já implica uma opção por uma carreira profissional a ser seguida na vida. A Universidade da Floresta disponibiliza apenas 10 cursos de graduação e a condição financeira dos alunos pesquisados não thes permite muitas outras alternativas como estudar em uma instituição particular ou migrar para a capital do estado do 


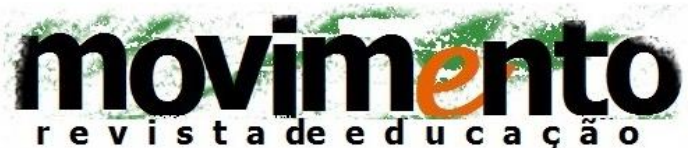 \\ faculdade de educação - programa de pós-graduação em educação \\ universidade federal fluminense \\ issn 2359-3296 \\ ano 5 número $9-2018$}

Acre ou para outro estado. Ao fim, a decisão dos nossos entrevistados torna-se um tanto limitada.

Ao serem questionados sobre a escolha do curso, 6 dos 10 alunos afirmaram que sempre tiveram afinidade e interesse pela área escolhida. Desses 6, 2 deles queriam cursar Medicina ${ }^{14}$, mas como acreditavam que não teriam chance de passar no vestibular e nem mesmo condições financeiras de morarem em Rio Branco, onde o curso funciona, optaram pelo curso de Enfermagem, menos concorrido e ofertado no campus da Floresta.

Mesmo que a maioria, 7 dos 10 alunos, tenha afirmado que a escolha do curso deu-se por afinidade e interesse pela área, 3 deles explicitaram motivos diferentes no momento de escolher o curso. Emanuel confessou que queria mesmo fazer o curso de Letras-Inglês, mas, por erro do seu irmão que estava em Cruzeiro do Sul e que fez a sua inscrição, colocou Letras-Espanhol. Silmara diz ter escolhido esse curso porque acreditava que, entre aqueles oferecidos no campus da Floresta, ele seria o que ela teria mais facilidade de conseguir vaga em um concurso público para professora no município onde mora (Mâncio Lima). Já Lúcia afirma estar cursando Letras-Espanhol simplesmente por não ter sido aprovada para Enfermagem, mas que continuará fazendo seleção até conseguir.

Em relação à concorrência, ao serem indagados se sabiam que os cursos escolhidos eram os mais concorridos do campus da Floresta, apenas um aluno confirmou ter conhecimento sobre isso.

\footnotetext{
${ }^{14}$ É válido enfatizar que a maior parte dos candidatos aprovados para Medicina na UFAC são originários de outros estados brasileiros. Dos 40 alunos formados no ano de 2014, apenas 12 são acreanos.
} 


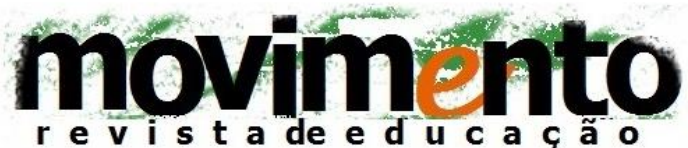 \\ faculdade de educação - programa de pós-graduação em educação \\ universidade federal fluminense \\ issn 2359-3296 \\ ano 5 número 9 - 2018}

Com relação às tentativas de ingresso dos entrevistados na Universidade da Floresta, apenas 2 garantiram suas vagas na primeira vez que fizeram a seleção. Para isso, ambos afirmaram terem se preparado bastante, principalmente no último ano do ensino médio e se dedicado com mais intensidade nessa fase. Dos outros 8 alunos, 4 conseguiram ingressar apenas na segunda ou na terceira tentativa, sendo que desses apenas 2 fizeram as 2 seleções para o curso em que hoje são acadêmicos. Já os outros 2, nas primeiras tentativas, procuraram outros cursos como Enfermagem (estudante atual do curso de Letras-Espanhol) e Ciências Biológicas Licenciatura (estudante atual do curso de Letras-Espanhol).

São diversos os relatos dos entrevistados sobre as suas experiências na universidade, principalmente no que diz respeito ao desempenho e às condições de permanência. Todos os alunos afirmam aproveitar bem o curso e ter um bom rendimento, apesar das grandes dificuldades que enfrentam para que nele possam permanecer.

Também discutindo a longevidade escolar de alunos de camadas populares no Brasil, ao realizar um trabalho de acompanhamento da situação de 56 filhos de 16 famílias que moravam na periferia urbana de Florianópolis entre os anos de 1991 e 1998, ZAGO (2006) tenta compreender quais os processos que explicam o porquê de a população em idade escolar deixar precocemente a escola, mas depois retornar. Neste sentido, a autora enfatiza que "a realidade social nos mostra que condições socioeconômicas similares, podem-se gerar percursos diferenciados" (ZAGO, 2006, p. 135), reforçando o argumento de que a mobilização familiar voltada para as atividades escolares do filho, as práticas de transmissão e socialização de valores, o apoio de um professor de forma sistemática, a demanda por parte da atividade profissional por melhor e mais escolaridade e o tipo de trajetória social e escolar podem se constituir em 


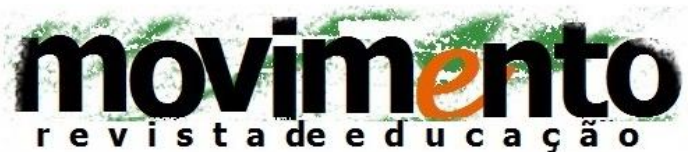 \\ faculdade de educação - programa de pós-graduação em educação \\ universidade federal fluminense \\ issn 2359-3296 \\ ano 5 número $9-2018$}

fatores escolarmente benéficos para produzir uma trajetória escolar longeva, mesmo que colegas de idade semelhante e da mesma origem social dirijam-se ao fracasso (ZAGO, 2000, p. 154).

Nesse sentido, em meio a todos os desafios que vêm sendo enfrentados pelos alunos pesquisados ao longo de suas vidas acadêmicas, a aquisição da bolsa Pró-Estudo não poderia deixar de ser mencionada como condição sine qua non para que todos permanecessem em seus respectivos cursos. Diante de tantos problemas econômicos enfrentados pelos discentes, para alguns, esse benefício tornou-se a única fonte de renda que tinham para se manterem na universidade. Antes mesmo de estarem no ensino superior, três deles já tinham informações sobre a sua existência: 1 soube através de seu irmão que já estudava na Universidade da Floresta; outro, através de um professor da UFAC que é natural de seu município e amigo de seu pai e 1 aluna obteve a informação quando ainda cursava o ensino médio, já que alguns alunos da UFAC foram até a sua escola palestrar para os formandos sobre as bolsas e auxílios existentes na instituição. Os demais alunos souberam através do site da Universidade (2), dos colegas de turma (2) e do mural da instituição (3). Todos esses afirmaram que pesquisaram o edital de maneira mais detalhada no site.

Vale ressaltar que a quantidade de bolsas oferecidas por essa instituição não atende à demanda por assistência estudantil. Além disso, o valor do benefício é baixo e não é suficiente para custear todas as despesas escolares.

\section{Conclusão}

A temática desse trabalho apresentou o percurso de jovens pobres no ensino superior público no interior do estado do Acre. Teve por objetivo analisar o 


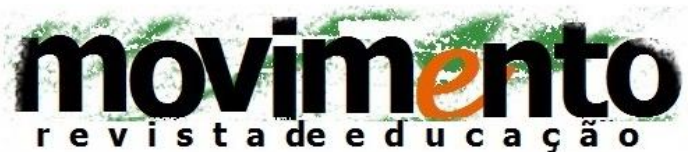 \\ faculdade de educação - programa de pós-graduação em educação \\ universidade federal fluminense \\ issn 2359-3296 \\ ano 5 número 9 - 2018}

acesso e a permanência desses estudantes nos cursos mais seletivos da Universidade Federal do Acre, Campus Floresta, e as estratégias adotadas por eles e por seus familiares para ingressarem e para dar continuidade ao ensino universitário.

A pobreza de alguns jovens é atestada pelo recebimento do Bolsa Família, trazendo, à tona, o cenário de encontro dessas duas realidades radicalmente opostas. Portanto, não basta somente a criação de políticas afirmativas de ingresso desses jovens oriundos das camadas populares à universidade pública. É preciso que haja mecanismos de permanência na educação superior.

No caso aqui analisado, a força do atributo familiar prepondera no estímulo e no apoio à escolaridade superior dos filhos. Dessa maneira, a sorte de se viver em um ambiente doméstico educógeno orientaria de forma decisiva o futuro dos estudantes. Não havendo essa possibilidade, seriam muito escassas as possibilidades deles avançarem nos estudos, posto que outras redes de sociabilidade, mesmo as informais, não são relevantes nos relatos.

Em outras palavras, são os contatos estabelecidos na ordem privada e não na pública que amparam os indivíduos em sua inserção e na sua mobilidade social, selando seus destinos muito próximos às suas origens. Além disso, nosso campo, interiorizado em região de fronteira, ainda penaliza o alunado na precariedade da infraestrutura urbana. Vale dizer que, embora o número de vagas em regiões interioranas tenha aumentado, se não houver transporte, trabalho, saúde, acesso aos direitos primários e à justiça (pagamento de pensões, por exemplo), os projetos de prolongamento da escolaridade podem ser inviáveis. 


\section{$\underset{r e v i s t a d e d u c i c s}{\operatorname{movim}}$ \\ faculdade de educação - programa de pós-graduação em educação \\ universidade federal fluminense \\ issn 2359-3296 \\ ano 5 número 9 - 2018}

\section{Referências}

BOURDIEU, Pierre; CHAMPAGNE, Patrick. Os excluídos do interior. In:

BOURDIEU, Pierre et al. A miséria do Mundo. 5 ed. Petrópolis: Vozes, 1997. p 481-486.

BRASIL. MEC. INDICADORES. 2015. Disponível em:

<http://gestao2010.mec.gov.br/indicadores/indicadores_agregados.php> Acesso em: 4 abr. 2014.

COULON, Alain. A condição de estudante: a entrada na vida universitária.

Salvador: Editora da Universidade Federal da Bahia (Edufba), 2008. Disponível em: <http://rbep.inep.gov.br/index.php/RBEP/article/viewFile/1835/1746>

DUBET, François. O que é uma escola justa? Cadernos de Pesquisa, v. 34, n. 123, p. 539-555, set./dez. 2004. Disponível em:

<http://www.scielo.br/pdf/cp/v34n123/a02v34123.pdf> Acesso dia 30 maio 2014.

ENADE. Relatório do Curso de Enfermagem 2013. Brasília, Setembro de 2014.

ENADE. Relatório do Curso de Letras Espanhol 2011. Brasília, Setembro de 2012.

EZCURRA, Ana Maria. Masificacion y ensenñanza superior: uma inclusiónexcluyente. Algunashipótesis y conceptos clave. In: Reformas e Democratização da Educação Superior. Aparecida, SP: Ideias e Letras, 2011. p. $97-120$.

FORQUIN, J.C. (Org). Sociologia da educação: dez anos de pesquisa. Trad. Guilherme João de Freitas Teixeira. Petrópolis, RJ: Vozes, 1995.

INEP. Sinopses Estatísticas da Educação Superior - Graduação. Disponível em: <http://portal.inep.gov.br/superior-censosuperior-sinopse> Acesso em: 10 set 2014.

LAHIRE, B. Sucesso escolar nos meios populares: as razões do improvável. São Paulo: Ática, 1997. 


\section{movimento \\ faculdade de educação - programa de pós-graduação em educação \\ universidade federal fluminense issn 2359-3296 \\ ano 5 número 9 - 2018}

NOGUEIRA, Maria Alice e NOGUEIRA, Claúdio Martins. Bourdieu\& a Educação. 3 ed. Belo Horizonte: Autêntica, 2009.

PAULA, Maria de Fátima Costa de; LAMARRA, Norberto Fernandéz. Reformas e Democratização da Educação Superior na América Latina. In: PAULA, Maria de Fátima Costa de e LAMARRA, Norberto Fernandéz. (Orgs.). Reformas e Democratização da Educação Superior no Brasil e na América Latina.

Aparecida, SP: Ideias e Letras, 2011. p. 53-96.

PLANO NACIONAL DE EDUCAÇÃO -2011. Disponível em:

$<$ http://fne.mec.gov.br/images/pdf/notas_tecnicas_pne_2011_2020.pdf> Acesso em: 22 mar 2014.

PNAES. Disponível em: <http://www.planalto.gov.br/ccivil_03/_Ato20072010/2010/Decreto/D7234.htm> Acesso em: 11 jan. 2014.

PORTES, Écio Portes. Trajetórias e Estratégias do universitário das camadas populares. Dissertação (Mestrado). Faculdade de Educação, Universidade Federal de Minas Gerais, Belo Horizonte, 1993.

SETTON, Maria da Graça Jacintho. Um novo capital cultural: pré-disposições e disposições à cultura informal nos segmentos com baixa escolaridade.

Educação e Sociedade, Campinas, vol. 26, n. 90, p. 77-105, abr. 2005.

SOUZA, Aline Nunes Ferreirinha. As Políticas Educacionais para o Ensino Superior da Ditadura Militar (1968 - 1985) e do Governo Lula da Silva (2003 2010) e seus Reflexos na Reformulação do Estatuto e Regimento Geral da UFRRJ (1970 - 2011). Universidade Federal da Paraíba, João Pessoa, PB, 2013. Disponível em:

<http://www.histedbr.fe.unicamp.br/acer_histedbr/seminario/seminario9/> Acesso em: 13 out. 2014.

VARGAS, Hustana Maria. Aqui é assim: tem curso de rico pra continuar rico e curso de pobre pra continuar pobre. In: 33a Reunião Anual da ANPEd, 2010, Caxambu, MG. Anais da Anped, 2010.

Sem perder a majestade: "profissões imperiais" no Brasil. Estudos de Sociologia, São Paulo, v. 15, p. 107-124, 2010. 


\section{movimento \\ faculdade de educação - programa de pós-graduação em educação \\ universidade federal fluminense \\ issn 2359-3296 \\ ano 5 número 9 - 2018}

ZAGO, Nadir. Do acesso à permanência no ensino superior: percursos de estudantes universitários de camadas populares. Revista Brasileira de Educação. v 11, n 32, Rio de Janeiro, Maio/Ago. 2006. Disponível em: $<$ http://www.scielo.br/scielo.php?pid=s1413-

24782006000200003\&script=sci_arttext> Acesso em 20 abr. 2014

\section{SOBRE AS AUTORAS}

ADRIANA MARTINS DE OLIVEIRA é doutoranda em Educação pela Universidade Federal do Paraná. Professora Assistente da Universidade Federal do Acre (UFAC).

E-mail: adrianamartinsczs2011@gmail.com

EDNACELI ABREU DAMASCENO é Doutora em Educação pela Universidade Federal de Minas Gerais (UFMG). Professora Adjunta da Universidade Federal do Acre (UFAC).

Universidade Federal Do Acre,

E-mail: ednaceli@yahoo.com.br

Recebido em: 24.08.2018

Aceito em: 24.10.2018 